ON THE RECORD

(CThe crocodile is showing no signs of life. We are not specialists and, to be honest, we don't know whether it's dead or alive.》

Rudimentary herpetology proves to be a bit too much for Nikolai Ranga, the Ukrainian emergency official charged with looking after Godzilla, recently recaptured after six months on the run from a travelling zoo.

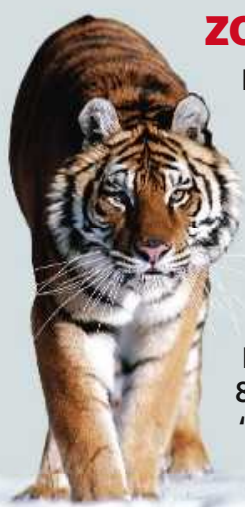

\section{ZOO NEWS}

Royal tigers

Rather like Europe's royal families, tigers at a breeding centre in China are having their family tree drawn up to ensure their bloodline remains pure. Keepers are DNA-testing the centre's 800 tigers to guard against 'intermarriage' that could dilute the tigers' precious gene pool.

\section{SCORECARD}

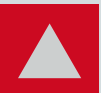

Battling obesity US health officials say obesity levels may be

hitting a plateau - although they're still running at one in three for both sexes.

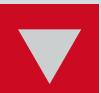

Battling incompetence Rhode Island Hospital has been fined $\$ 50,000$ after the third instance this year of brain surgeons operating on the wrong side of a patient's head.

\section{NUMBER CRUNCH}

50 is the number of endangered humpback whales scheduled to be caught by Japanese researchers this year - a quota that has angered conservationists.

11,000 is the number of potential names suggested for the migrating whales being tracked as part of Greenpeace International's campaign to save them. Supporters can vote online for their favourites.

$75 \%$ is the proportion of voters who chose 'Mister Splashy Pants' as their preferred name.

Sources: Reuters, Xinhua.net, AP, Greenpeace International

\title{
Saudi-Italian biomedical institute gets go-ahead
}

Saudi Arabia has come a step closer to attaining a world-class level of research with the first signed agreement between the kingdom and a Western biomedical institute.

On 26 November, two oncology institutes in Milan, Italy, signed a Memorandum of Understanding with representatives of the Saudi Arabia General Investment Authority (SAGIA). The institutes will help to train Saudi Arabian students, advise Saudi authorities on the creation of a hospital and cancer research centre and collaborate in research projects.

Saudi Arabia, which has not invested much in basic science in the past, is now actively trying to buy its way into the world of cutting-edge research. Earlier "Many more women are working in Saudi Arabian hospitals and research centres."

which was created in April when the FIRC Institute of Molecular Oncology (IFOM) and the European Institute of Oncology (IEO) moved to one site. The campus is the core of a consortium there that includes university institutes and biotech firms, and incorporates research training, technology development and technology transfer. Marco Foiani, a scientific director at the IFOM, says that SAGIA got things moving very quickly after first making contact with their campus in spring this year. Italian scientists visited Saudi Arabia in summer and will start teaching at universities there next year. "We will take the opportunity to scout for talent for our $\mathrm{PhD}$ programmes this year, it founded the King Abdullah University of Science and Technology (KAUST) with a US\$10-billion endowment (see Nature 447, 758-759). It also has plans to create from scratch four new 'economic cities'. The planned research hospital will be part of the King Abdullah Economic City being developed on a 168 squarekilometre site close to the Red Sea near the cities of Jiddah, Mecca and Medina.

The SAGIA wants to model its research activities on Milan's IFOM-IEO campus, in molecular medicine, nanomedicine and bioethics," Foiani says.

The two sides have agreed that Saudi students should be recruited for the IFOM-IEO's highly competitive, international $\mathrm{PhD}$ programmes from next October. Saudi Arabia has little experience in biomedicine, but senior scientists at the Milan campus insist that they will not lower standards to favour one nation. "It's a difficult part of the story - but we are committed to finding a way to implement it,"

\section{Asia plans first cancer network}

Cancer researchers from around Asia met in Nanjing, China, last month to hammer out plans for a regional network to coordinate epidemiology data and prevention.

The network would gather data from cancer registries in countries from the Philippines to Turkey - an area that has two-thirds of the world's population and more than half of its 7.6 million cancer deaths each year, according to the World Health Organization. Most of these nations have registries, but the data are not always accurate or standardized, says Kazuo Tajima, director of the Aichi Cancer Centre Research Institute in Nagoya, Japan, who is one of the meeting's organizers. "There is currently no way to compare notes," he says.

The Asian Cancer Registry and Information Network, as it is being mooted, would establish the region's first hub - probably in Japan - to hold standardized data, which could then be used for epidemiological research, cancer risk assessment and prevention planning. It would offer some of the less-developed countries in the region a chance to catch up with modern diagnostic techniques and offer comparisons that might help figure out why, for example, incidence of liver cancer is so high in Mongolia.

The network would also offer an opportunity to tease out the role of Asian genes in the

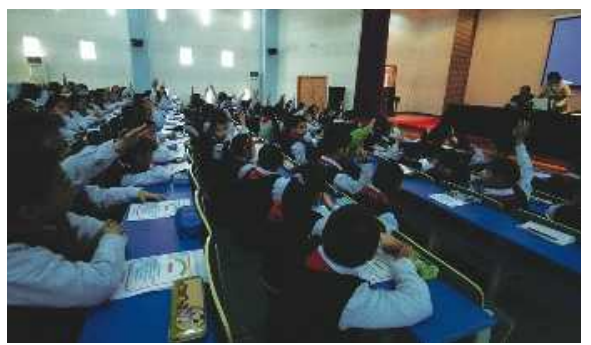

Cancer education can break down cultural barriers. 


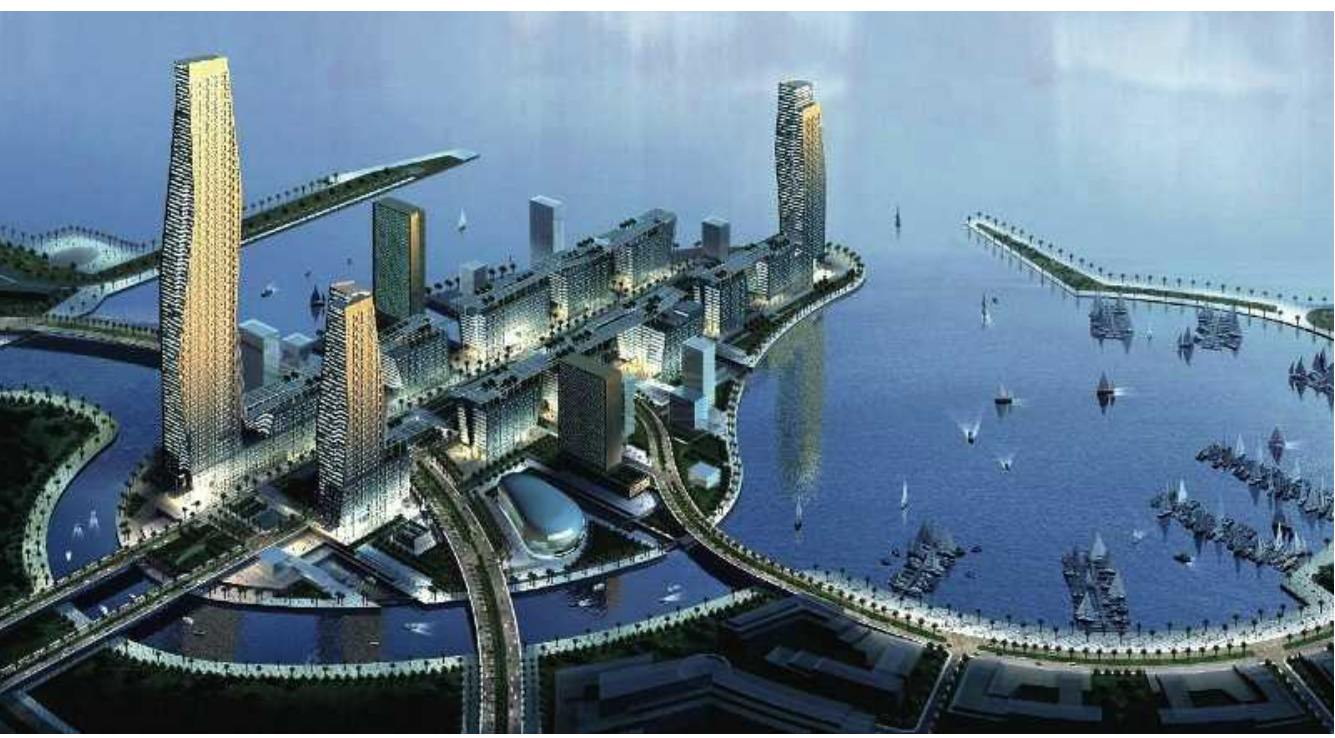

The King Abdullah Economic City will be home to a world-class research facility.

says Pier Giuseppe Pelicci, head of experimental oncology at the IEO.

Another difficulty, says Foiani, will be the problems that women researchers face in a country that allows them so little freedom of movement. "Culturally, it is another world," he says. But Manar Al-Moneef, head of SAGIA's life-sciences sector, says that she expects a "big improvement" in conditions for women soon. "Many more women are working in hospitals and research centres than a few years ago things are getting better rapidly," she says.

Saudi and Italian scientists will meet next month to sort out the details, and to identify the research programmes on which they will collaborate. One such programme could be breast cancer, says Foiani. The disease has a high priority in Saudi Arabia, where intermarriage within families has led to an above-average rate of breast cancers with unusual genetic mutations.

Financial arrangements for the initiative have not yet been negotiated. A few months ago SAGIA signed a \$5.3-billion deal with international partners, including Fraunhofer research institutes in Germany to develop BioSphere, a biotechnology science park planned for the Abdullah city.

Alison Abbott development of some cancers and the reaction to particular drugs. "Most of the data used in cancer studies are from Westerners," says Sumio Sugano, a genomics specialist at the University of Tokyo who attended the International Union against Cancer (UICC) symposium in Nanjing. "This is a chance to use Asian data."

The organizers anticipate difficulties stemming from concerns over the privacy of data. "We have to move one step at a time," says Sugano. "Building trust among researchers is the first step." Organizers of the meeting hope that the network's activities can bridge some of the animosity present in the historicaly fractious region. The meeting was funded by Japan's Ministry of Health, Labour and Welfare, partly to celebrate the 35th anniversary of normalization of Sino-Japanese diplomatic relations. The next meeting will be in Manila in March.

Norie Kawahara, a research fellow at the Research Center for Advanced Science and Technology at the University of Tokyo, says the site location, Nanjing, where hundreds of thousands of Chinese were massacred by the Japanese military 70 years ago - an event that is denied by some right-wing historians in Japan - was a symbolic choice.

A few years ago, when Kawahara started pushing the idea of a Japan-led Asian network, she says people refused, thinking that it sounded like a return to the Greater East Asian Co-Prosperity Sphere, the euphemistic name that Japan gave to its colonizing activities in the region. She hopes that through such activities as the anti-smoking, anti-cancer campaign she ran in a parallel session at last month's meeting, targeted at Chinese and Japanese children, she can "use science to rewrite history".

Tajima is applying for $¥ 60$ million (US\$542,000) over 3 years to push Japan's role as a hub for the network in the future. "But we won't need gigantic sums of money," says Malcolm Moore, head of the UICC Asia regional office in Bangkok. "What is needed is for people to get together and participate."

David Cyranoski
AMERICAN SOCIETY FOR CELL BIOLOGY Find meeting reports in our conference blog. http://blogs.nature. com/news

\section{Fund boost for German science}

Science was the big winner in Germany's budget, approved last week. The Christian Democrat-Social Democrat majority approved a record $9.8 \%$ increase in the federal budget for science and education for 2008.

The German coalition government had promised to boost investment in science and, almost uniquely for a budget proposal, this passed through parliament without any cuts. The Ministry for Education and Research (BMBF) will receive $€ 9.35$ billion (US $\$ 13.7$ billion) next year - a whopping $€ 150$ million more than the government had initially proposed in July.

Germany's research council, the DFG, which funds most university research, will see a $3 \%$ rise next year in its $€ 1$.6billion budget. Non-university research organizations, including the Max Planck Society, the Fraunhofer Society, which runs centres

for applied research, and the Helmholtz Association, which runs Germany's 15 national research centres, will also "It's good to see that awareness of the importance of science is on the rise." receive around $3 \%$ more money each. The BMBF also directly funds basic and applied science in fields of strategic importance, including health and climate research. Its grants will increase by $18 \%$ to $€ 3.5$ billion, including $€ 285$ million for winning universities in the government's 'excellence initiative' (see Nature 450, 452-453; 2007).

"This is a substantial growth," says Matthias Kleiner, the president of the DFG. "It's good to see that awareness of the importance of science is on the rise in Germany."

But although financial conditions for science have improved, scientific salaries in Germany are not internationally competitive, warns Rudi Balling, scientific director of the Helmholtz Centre of Infection Research in Braunschweig. "There's fresh money available to do many exciting things here, but we run the risk of losing the best people just because they can earn so much more abroad."

Quirin Schiermeier 